\title{
Small Fruit Production in High Tunnels
}

\author{
Kathleen Demchak ${ }^{1,2}$
}

\begin{abstract}
AdDITIONAL INDEX wORDs. protected culture, season extension, Fragaria $\times$ ananassa, Rubus, Vaccinium, strawberry, raspberry, blackberry, blueberry

SUMMARY. High tunnels are a relatively economical form of protected culture, and offer cultural advantages such as protection from the elements and an extended production season. Interest in high tunnels for small fruit production has been increasing in North America. Growers in the United States and Canada are using multi-bay and single-bay high tunnels for production of red raspberry ( $R u b u s$ idaeus), black raspberry ( $R$ ubus occidentalis), blackberry ( $R u b u s$ subgenus $R u b u s$ ), strawberry (Fragaria $\times$ ananassa), and blueberry (Vaccinium spp.). Research trials using high tunnels are being conducted in numerous places across the United States. In most instances, high tunnels increased yields of berry crops, improved quality, and decreased the incidence of most diseases compared with field production, powdery mildew (Sphaerotheca macularis) being a notable exception. The insect and mite complex encountered in tunnels when growing berry crops has changed markedly, often becoming similar to that which might have been expected in greenhouses, with numbers of two-spotted spider mite (Tetranychus urticae), whitefly (Aleyrodidae), and thrips (Frankliniella spp.) reaching high levels without control measures. In studies at The Pennsylvania State University, primocane-bearing cultivars of red raspberry plants produced at least two to three times as much marketable fruit in tunnels as in a previous field study, with substantial summer and fall crops obtained. 'Triple Crown' thornless blackberry produced very high marketable yields in the tunnels, even though winter injury historically resulted in a lack of blackberry production in the field. Strawberry production in a plasticulture system using short-day or day-neutral cultivars was found to be viable; however, the primary benefit of high tunnels for strawberry may have been reliability of production rather than a yield increase. Potential reasons for improvements in productivity and quality are numerous and warrant further attention.
\end{abstract}

\section{High tunnel usage for small fruit crops}

In the past, protected culture including use of high tunnels was used to a great extent in other countries, and to a lesser extent in the United States (Hancock and Simpson, 1995; Wittwer and Castilla, 1995). Strawberry was the fruit crop most widely grown worldwide under high tunnels and greenhouses (Wittwer and Castilla, 1995), and with the use of plastic films overall (Wittwer, 1993).

In the United States and Canada, growers are using high tunnels for raspberry, blackberry, strawberry, and blueberry production. Data on U.S. acreage in high tunnel production are scarce, but it appears that for small fruit crops, the greatest acreage in high tunnels is probably in California, where much of the raspberry acreageover 4000 acres (U.S. Department of

Department of Horticulture, The Pennsylvania State University, 102 Tyson Building, University Park, PA 16802

${ }^{1}$ Senior Extension Associate.

${ }^{2}$ Corresponding author. E-mail: kdemchak@psu.edu.
Agriculture, 2008)-is from plants that are covered while they are producing fruit (T. Sjulin, personal communication). An estimated 100 acres of blackberry and blueberry are produced under tunnels in Oregon (B. Strik, personal communication), and $\approx 10$ acres of raspberry are produced under tunnels in British Columbia (C. Kempler, personal communication). About 14 acres of high tunnel brambles are located in Ontario ( $P$. Fisher, personal communication). Nearly all of the above acreage is under multi-bay tunnels and the vast majority of the raspberries produced are from primocane-bearing cultivars.
In states mostly in the upper-midwestern and northeastern United States, single-bay tunnels are more commonly used than multi-bay tunnels. In these regions, most growers of high-tunnel berries have diversified farming operations, with hightunnel fruit comprising only a portion of their operations, and acreage of high-tunnel small fruit production is low, with several states having between 0.1 and 2 acres. When one considers that a single 24 -ft-wide by 300 -ft-long bay of a multi-bay tunnel occupies 0.16 acres, and that a $17-\mathrm{ft}-$ wide by 96 -ft-long single-bay high tunnel occupies only 0.04 acres, it is apparent that it would take many small-scale high-tunnel berry producers to add up to substantial acreage.

Tunnels are used for protection from the elements, environmental modification, or season extension (Lamont, 2005; Wells and Loy, 1993). Frequently, the methods recommended for growing small fruit crops in high tunnels are very similar to those recommended for field production with relatively minor changes in irrigation timing, amount, and type; fertilization methods; and pruning techniques (Heidenreich et al., 2007; Jett, 2007; Lamont et al., 2006). Pesticide usage may be markedly decreased, however, and biological or cultural controls can play a significant role in pest management (Heidenreich et al., 2007; Lamont et al., 2006). Less frequently, production methods may be used that are more similar to greenhouse production than to field production. In these cases, plants are grown in containers that may be pots for raspberry, or table-top or gutter systems in the case of strawberry.

\section{High tunnel research on small fruit crops}

There are only a few articles documenting U.S. or Canadian high

\begin{tabular}{llll}
\hline $\begin{array}{l}\text { Units } \\
\text { To convert U.S. to SI, } \\
\text { multiply by }\end{array}$ & U.S. unit & SI unit & $\begin{array}{l}\text { To convert SI to U.S., } \\
\text { multiply by }\end{array}$ \\
\hline 0.4047 & acre $(\mathrm{s})$ & $\mathrm{ha}$ & $2.471 \mathrm{l}$ \\
0.3048 & $\mathrm{ft}$ & $\mathrm{m}$ & 3.2808 \\
2.54 & inch $(\mathrm{es})$ & $\mathrm{cm}$ & 0.3937 \\
0.4536 & $\mathrm{lb}$ & $\mathrm{kg}$ & 2.2046 \\
1.1209 & $\mathrm{~b} / \mathrm{acre}$ & $\mathrm{kg} \cdot \mathrm{ha}^{-1}$ & 0.8922 \\
1.4882 & $\mathrm{lb} / \mathrm{ft}$ & $\mathrm{kg} \cdot \mathrm{m}^{-1}$ & 0.6720 \\
1 & $\mathrm{mmho} / \mathrm{cm}$ & $\mathrm{dS} \cdot \mathrm{m}^{-1}$ & 1 \\
28.3495 & $\mathrm{OZ}$ & $\mathrm{g}$ & 0.0353 \\
$\left({ }^{\circ} \mathrm{F}-32\right) \div 1.8$ & $\mathrm{o} F$ & ${ }^{\circ} \mathrm{C}$ & $\left(1.8 \times{ }^{\circ} \mathrm{C}\right)+32$
\end{tabular}


tunnel research on small fruit crops in the scientific literature, although numerous reports on greenhouse small fruit production can be found. According to Gaskell et al. (2004), small fruit producers in California began experimenting with high tunnels for season extension during the early 1990s. Through research and development work conducted by large shippers of small fruit in California, cultural practices were worked out that allowed an increase in raspberry production for an extended season. This work also included trials with blueberry and blackberry. Within the northeastern United States, Otho Wells at the University of New Hampshire was probably the first person to introduce the concept of growing berries in high tunnels (Moore, 2000). Lamont et al. (2003) provided an overview of crop production in research high tunnels at The Pennsylvania State University (Penn State), including mention of work on brambles and strawberry.

Recently, the amount of research being conducted in high tunnels has mushroomed. At this time, a search for high tunnel research projects on the Web reveals that currently or within the last 3 years, research projects on high-tunnel small fruit production has been taking place in more than 20 U.S. states or Canadian provinces (Arkansas, California, Georgia, Iowa, Kansas, Maryland, Michigan, Minnesota, Missouri, Mississippi, New Hampshire, New York, North Carolina, Ohio, Ontario, Oregon, Pennsylvania, South Carolina, Utah, Virginia, and West Virginia). Most of this reported research is on strawberry or raspberry, with smaller amounts of research taking place on blackberry or blueberry. A summary of these projects at this time would be impossible. However, experiences with high-tunnel berry production at Penn State will be shared below.

In Pennsylvania, research trials on red and black raspberry, blackberry, June-bearing and day-neutral strawberry, and/or hardy kiwi (Actinidia arguta) have been underway since 2000 , and results from concluded studies will be covered. The high tunnel complex is located at Penn State's Russell E. Larson Agricultural Research Center at Rock Springs, PA (Rock Springs) (lat. $41^{\circ} \mathrm{N}$, USDA Hardiness Zone 6a). At this location, the last spring frost usually occurs during the latter half of May, and the first fall frost during the first week of October. Although average annual minimum temperatures are in the -5 to $-10{ }^{\circ} \mathrm{F}$ range, reaching -15 to $-20^{\circ} \mathrm{F}$ is not unusual.

The relatively short growing season at this site presents some problems for field production of small fruit crops; specifically, much of the potential fall harvest of primocane-bearing raspberry remains unharvested due to the early first fall frost, thornless blackberry floricanes fail to survive the winter, and use of the strawberry plasticulture system requires a planting date that precedes typical plug plant availability.

High TUNNELS FOR SEASON EXTENSION OF 'HERITAGE' AND 'AUTUMN BRITTEN' PRIMOCANEBEARING RED RASPBERRY, 2000-05. The original question concerning high-tunnel raspberry production was to what extent season extension in the fall would affect yield because in an earlier research study conducted at Rock Springs from 1994 to 1997 , only $18 \%$ and $50 \%$ of the potential fall crop was harvested from the cultivars Heritage and Autumn Britten, respectively (Goulart and Demchak, 1999), before fall frosts halted harvest.

The first planting of raspberry was established in mid-Apr. 2000. 'Heritage' and 'Autumn Britten' red raspberry were grown in the soil in a randomized complete-block design with two blocks in one tunnel. Rows were on 8 -ft centers. In another tunnel, these cultivars were grown in Earth Box ${ }^{\circledR}$ containers (Earth Box ${ }^{\circledR}$, Scranton, PA), which are rectangular plastic boxes 29 inches long by 13.5 inches wide by 11 inches deep with a water-holding chamber in the lower portion of the container. While plants grew well in Earth Boxes ${ }^{\circledR}$, this system was eventually abandoned, as sufficient watering and stable trellising were more difficult to maintain compared with in-ground production. During the 2000 growing season, a decision was made to apply pesticides only if disease or pest pressure necessitated application, as it seemed that high tunnel production was having a desirable impact on disease incidence due to the lack of moisture on the leaves and canes.
Results from the in-ground raspberry study yielded a plethora of interesting results. The planting date in 2000 was about a month earlier than would have been possible for field production on this site due to the early workability of the soil in the tunnel. Yields obtained from 'Autumn Britten' during fall of the establishment year, at $0.94 \mathrm{lb} / \mathrm{ft}$ of row (linear), equivalent to $5118 \mathrm{lb} /$ acre, were very similar to yields obtained from 'Polana' and 'Caroline' 2 and 3 years after establishment in the field in an earlier study (Goulart and Demchak, 1999).

'Heritage' had just begun to produce ripe fruit in 2000 when cold temperatures stopped production (in part, due to a mismanagement of venting). Canes were much taller than usual for this site, reaching over $7 \mathrm{ft}$ tall, therefore a decision was made to remove the dead fruited tips from the canes the following spring and produce a summer crop. 'Autumn Britten' canes were less than $4 \mathrm{ft}$ tall after the dead tips were removed, leaving little floricane length to bear fruit, therefore this cultivar was then pruned to the ground. Canes of 'Heritage' were thinned to the standard four to six canes per linear foot of row recommended for this region, and a respectable summer yield of $0.78 \mathrm{lb} /$ $\mathrm{ft}$ of row, equivalent to $4247 \mathrm{lb} / \mathrm{acre}$, was obtained (Table 1). The fall crop in 2001 was very heavy with both cultivars, and the season total far exceeded expectations, at $2.52 \mathrm{lb} / \mathrm{ft}$ of row for 'Autumn Britten' and $4.25 \mathrm{lb} / \mathrm{ft}$ of row for 'Heritage'. In 2002 and 2003, when summer and fall crops were harvested from both cultivars, it became apparent that the balance between the two crops could be drastically affected. Floricanes were not thinned during dormant pruning in 2002, and a very heavy summer crop was followed by a reduced fall crop. Thinning the floricanes to five per linear foot of row in late winter in 2003 brought 'Heritage' yields back to a similar proportion as in 2001, although 'Autumn Britten' still produced most of its crop during the summer.

The planting was thereafter maintained primarily for demonstration through 2007. In all years except the establishment year, each cultivar bore its fall crop $\approx 1$ month earlier in 
Table 1. Marketable yield of two raspberry cultivars grown in high tunnels at Rock Springs, PA, during 2001-03. Rows were on 8-ft $(2.4 \mathrm{~m})$ centers. Plants were planted in 2000 in flat beds, were trickle-irrigated, and were grown in a nearly pesticide-free system. Plants were harvested two or three times per week.

\begin{tabular}{|c|c|c|c|}
\hline & $\begin{array}{c}\text { Summer yield } \\
\text { (from floricanes) }\end{array}$ & $\begin{array}{c}\text { Fall yield } \\
\text { (from primocanes) }\end{array}$ & $\begin{array}{c}\text { Season-long } \\
\text { yield }\end{array}$ \\
\hline Year/cultivar & & $(\mathrm{lb} / \mathrm{ft} \text { of row })^{\mathrm{z}}$ & \\
\hline \multicolumn{4}{|l|}{$2001^{y}$} \\
\hline Heritage & 0.78 & 3.47 & 4.25 \\
\hline Autumn Britten & - & 2.52 & 2.52 \\
\hline \multicolumn{4}{|c|}{2002 (variable number of floricanes per foot of row) } \\
\hline Heritage & 2.12 & 1.91 & 4.03 \\
\hline Autumn Britten & 2.41 & 0.72 & 3.13 \\
\hline$P>\mathrm{F}^{\mathrm{x}}$ & 0.23 & 0.08 & 0.02 \\
\hline \multicolumn{4}{|c|}{2003 ( 5 floricanes $/ \mathrm{ft}$ of row $)^{\mathrm{w}}$} \\
\hline Heritage & 0.70 & 1.99 & 2.69 \\
\hline Autumn Britten & 1.61 & 1.01 & 2.62 \\
\hline$P>\mathrm{F}$ & 0.02 & 0.25 & 0.91 \\
\hline
\end{tabular}

${ }^{\mathrm{z}} 1 \mathrm{lb} / \mathrm{ft}=1.488 \mathrm{~kg} \cdot \mathrm{m}^{-1}=5445 \mathrm{lb} / \mathrm{acre}=6103.0 \mathrm{~kg} \cdot \mathrm{ha}^{-1}$

'Heritage' canes were pruned to a density of four to six canes per foot of row (13.1-19.7 canes/m) and 'Autumn Britten' was pruned to the ground during dormant pruning in late Winter 2001. Therefore, no summer fruit was obtained from 'Autumn Britten' in 2001.

'From analysis of variance using PROC GLM (SAS, version 9.1.3; SAS Institute, Cary, NC).

w 1 floricane $/ \mathrm{ft}=3.2808 / \mathrm{m}$

the tunnel than would be typical for field production. This was presumably because plants began growing at least 4 weeks earlier in the spring than in the field. As a result, cultivars that are too late for field production in a given location could be grown in a tunnel. Due to producing a summer and fall crop on each of two cultivars, harvest in the tunnels took place from late June or early July through late October in each year.

Berry size was larger than typical for the cultivars grown, and shelf life was excellent, although no fungicides were used in the planting. Gray mold (Botrytis cinerea) was nearly nonexistent except in 2003 when a lack of sufficient harvest labor resulted in a greater incidence of missed raspberries than in other years.

Plants had been grown following standard field recommendations for fertilizer application, therefore only nitrogen was applied in each of the first 3 years. However, symptoms of what appeared to be potassium deficiency were noted, and a tissue test revealed that leaf potassium levels had reached a deficiency level. Thereafter, plants were fertilized with fertilizer that was balanced in nitrogen and potassium. This increased leaf potassium levels, but did not completely eliminate the deficiency.

The primary pests in the tunnels were two-spotted spider mite and whitefly, although thrips, aphids
(Aphididae), and potato leafhopper (Empoasca fabae) were also present. Japanese beetle (Popillia japonica) was problematic in 2001 , but the beetles were not as numerous in the tunnel as they were in the field. Eventually, the plants in high tunnels exhibited viral symptoms, probably due to viral transmission from wild raspberry in the vicinity, and were removed in 2007.

High-Density High TUNNEL BRAMBLE PLANTING, 2001-03. In 2001 , a tunnel of brambles was established on a close spacing, with the primocane-bearing raspberry 'Heritage', 'Deborah', 'Josephine', and the summer-bearing wyeberry (a red raspberry and blackberry cross) 'QDE-Fl' in rows that were on 4 - $\mathrm{ft}$ centers. This experiment was in a Latin square design with four blocks. Plants were harvested in 2002 and 2003. Per area total yields were comparable to the original tunnel, but gray mold incidence was relatively high, and keeping the aisles free of canes to move through the tunnel was difficult. Consequently, this planting was discontinued after 2003.

BLACKBERRY TRIAL, 2000-05. Over a 6-year span in a previous field study at this site, floricanes of five blackberry cultivars including the cold-hardy Chester failed to leaf out each spring, although vegetative growth was vigorous during each growing season (B. Goulart, unpublished data). This injury had been attributed to cold winter temperatures or damage from fluctuating spring temperatures. In a high-tunnel planting of 'Triple Crown' established in 2000, blackberry never suffered any floricane dieback during 2001-04, and yields over the 4 years averaged the equivalent of over $25,000 \mathrm{lb} /$ acre (Table 2). Berry size and berry quality remained good throughout all 4 years. Unfortunately, a buildup of raspberry crown borer (Pennisetia marginata) in the crowns of the blackberry plants resulted in the demise of the planting, and plants were removed in early 2006. There may already have been an effect of crown borers in 2004, as yields appeared to be decreasing at that point, although not significantly.

Planting date $\times$ strawberry CUltivar trial, 2000-01. The first trial at Penn State, conducted in 2000-01, compared planting dates of 'Chandler', 'Camarosa', and 'Sweet Charlie' plug plants in the high tunnels to field production in an annual raised bed plasticulture system. The field study and tunnel study used randomized complete block designs with four and two blocks, respectively, but statistical comparisons could not be made between tunnel production and the field due to a lack of replication comparing tunnel and field. Conclusions were that 'Chandler' was best for yields and quality in the field and tunnel, 'Sweet Charlie' bloomed too early in the tunnels (mid-January), and yields of 'Chandler' from plug

Table 2. Yield of 'Triple Crown' blackberry grown in high tunnels at Rock Springs, PA, during 2001-04. Rows were on 8 - $\mathrm{ft}(2.4 \mathrm{~m})$ centers. Plants were planted in 2000 in flat beds, were trickle-irrigated, and were grown in a pesticide-free system. Plants were harvested two or three times per week.

\begin{tabular}{|c|c|c|c|}
\hline Year & $\begin{array}{c}\text { Marketable } \\
\text { yield (lb/ft } \\
\text { of row })^{\mathrm{z}}\end{array}$ & $\begin{array}{c}\text { Marketable } \\
\text { fruit } \\
(\%)\end{array}$ & $\begin{array}{c}\text { Mean } \\
\text { berry } \\
\text { wt }(g)^{z} \\
\end{array}$ \\
\hline 2001 & 3.62 & 81.7 & 5.81 \\
\hline 2002 & 5.32 & 89.1 & 5.36 \\
\hline 2003 & 5.40 & 86.7 & 7.53 \\
\hline 2004 & 4.30 & 91.5 & 6.72 \\
\hline
\end{tabular}


plants planted in mid-September in the tunnel were fairly high, at $1.25 \mathrm{lb}$ of fruit per plant (data not shown). This yield was higher than that August planting date in the field, although not statistically comparable. It appeared that high tunnels could play a role in easing plug plant supply shortages for growers in USDA Hardiness Zones $7 \mathrm{a}$ and cooler by bringing the date for which plug plants are needed into better alignment with supply.

DAY-NEUTRAL STRAWBERRY IN A GUTTER SYSTEM. In 2001-02, eight cultivars of June-bearing strawberry were grown in a gutter system, but the year-long period of care relative to the amount of fruit produced and labor required was not justified. In 2003, the day-neutral 'Mara Des Bois', planted in a gutter system in fall, produced $0.30 \mathrm{lb}$ of high-quality fruit per plant, leading the way to a trial comparing eight cultivars of dayneutral strawberry in gutters in 2004 (Table 3 ). Conclusions were that dayneutral strawberry production in tunnels had potential, but management of gutters could be difficult, especially in the area of moisture management. Frequent watering was needed on hot sunny days, but leaving the plants on a schedule quickly resulted in overwatering on cool cloudy days. Yields were acceptable, but not higher than what would be expected from field production. Overall, 'Seascape' was the best performer considering marketable yields, mean berry weight, flavor, and texture. Total yields of obtained with the optimal midmid-July and harvested through the

'Tribute' and 'Tristar' were not different from that of 'Seascape' (data not shown), but the much smaller berry size, and hence lower percentage of marketable fruit, caused marketable yield per plant to be much lower.

JUNE-BEARING AND DAY NEUTRAL STRAWBERRY, RAISED-BED PLASTICUlTURe, 2005-06. This project compared four short-day cultivars and three day-neutral cultivars of various plug types in a plasticulture system planted in mid-September. Unfortunately, due to heavy fertilization of the previous crop, high salt levels in the tunnel $(3.85 \mathrm{mmho} / \mathrm{cm})$ resulted in symptoms of leaf burn appearing soon after planting. Repeatedly flushing the beds by irrigating for five 8-h episodes moved salts out from under the plastic and into the row middles, eventually resulting in symptom alleviation, but plants were not symptom-free until about 2 months after planting. Plants were harvested the following year from early May until mid-July. 'Chandler' was still the top-performer among short-day cultivars, producing $0.80 \mathrm{lb}$ of fruit per plant despite the setback from high salt levels, and day-neutral selections 'NCL 0305 ' and 'NCL 03-08' produced 1.5 and $1.4 \mathrm{lb}$ of fruit per plant, respectively.

\section{Discussion}

RASPBERRY. Raspberry yields in high tunnels have been high in locations other than Rock Springs. In Pennsylvania, certainly the longer growing season compared with the

Table 3. Yield of day-neutral strawberry cultivars grown in a high tunnel in a gutter system at Rock Springs, PA, during 2004. Plants were planted on 15-16 Apr. and harvested two or three times per week.

\begin{tabular}{lccc}
\hline Cultivar & $\begin{array}{c}\text { Marketable yield } \\
(\mathbf{l b} / \text { plant })^{\mathbf{z}}\end{array}$ & $\begin{array}{c}\text { Marketable fruit } \\
(\%)\end{array}$ & $\begin{array}{c}\text { Mean berry } \\
\mathbf{w t}(\mathbf{g})^{\mathbf{z}}\end{array}$ \\
\hline Tribute & 0.30 & 42.0 & 6.9 \\
Tristar & 0.19 & 23.1 & 6.0 \\
Seascape & 0.47 & 62.8 & 9.6 \\
Diamante & 0.36 & 70.2 & 12.7 \\
Aromas & 0.46 & 68.3 & 11.1 \\
Selva & 0.29 & 56.5 & 9.4 \\
Fern & 0.41 & 55.5 & 8.2 \\
Quinault & 0.06 & 10.5 & 5.8 \\
LSD $^{\mathrm{y}}$ & 0.14 & 8.33 & 0.87 \\
$P>\mathrm{F}^{\mathrm{x}}$ & $<0.0001$ & $<0.0001$ & $<0.0001$ \\
\hline
\end{tabular}

${ }^{\mathrm{z}} \mathrm{l} \mathrm{lb}=0.4536 \mathrm{~kg}, \mathrm{lg}=0.0353 \mathrm{oz}$.

${ }^{y}$ Fisher's protected least significant difference.

${ }^{x}$ From analysis of variance using PROC GLM (SAS, version 9.1.3; SAS Institute, Cary, NC). field could have played an important role. Here, the season was extended by 3 to 4 weeks in the fall, and an additional 3 to 4 weeks in the spring, resulting in a growing season that was $50 \%$ longer when compared with field production. In addition, less windy conditions in the tunnel than in the field may have resulted in more hours of photosynthesis taking place per day. In an earlier field study on this site, plants appeared to cease photosynthesis as soon as wind speed began to increase during the afternoon (B. Goulart, unpublished data). A recent study in New Brunswick, however, indicated that wind did not affect photosynthesis (Privé and Allain, 2000), therefore perhaps other factors such as humidity or soil moisture were also involved. In addition, the more diffuse light conditions in the tunnel may have resulted in more light reaching lower leaves, and increased photosynthesis rates.

BlackBerry. Why do high tunnels improve blackberry survival? The first hypothesis might be that warmer temperatures in the tunnel would account for the improved cane survival. However, a comparison of low temperatures during Jan. 2002, the coldest month of the year, found lows to average only $1.5^{\circ} \mathrm{F}$ higher inside the tunnel than outside. The difference between minimum temperatures inside and outside the tunnel varied widely among individual nights, apparently affected by cloud cover during the previous day and wind speed. An examination of temperatures during March showed that a low temperature of $9^{\circ} \mathrm{F}$ occurred on 5 March when the plants would be thought to be less than fully dormant, especially considering that during the $21 \mathrm{~d}$ before $5 \mathrm{Mar}$., temperatures inside the tunnel reached or exceeded $70{ }^{\circ} \mathrm{F}$ on $11 \mathrm{~d}$.

Higher minimum temperatures, or less fluctuation in spring temperatures, appeared not to account for why blackberry floricanes survived the winter. However, tunnels were kept closed during the winter, therefore less dessication of the canes from wind could have played a role. Also, due to the vigorous growth in the tunnels, the plants may have had higher carbohydrate reserves than usual. Other possibilities are that because the soil was not frozen in 
the spring, plants could have avoided becoming desiccated during periods of fluctuating temperatures, or because higher daytime temperatures occur in the tunnel during the winter than in the field, the chilling requirement may have been fulfilled more slowly (F. Takeda, personal communication). Also, high temperatures have been documented to have a negating effect on fulfilling the chilling requirement with peaches (Couvillon and Erez, 1985), therefore a similar effect of high temperatures in the tunnels could have kept the raspberry dormant until later in the winter. Recent research conducted at Michigan State University with raspberry indicated that raspberry buds are acclimated to cold temperatures at a later date in the tunnel that in the field (Vonweihe and Hanson, 2008), therefore the rest period may begin at a later date than for field plants.

STrawberry. A raised-bed plasticulture system worked well in tunnel production, a conclusion also reached by Kadir et al. (2006), and planting as much as 1 month later than the optimal date for field planting still resulted in acceptable yields. Growing day-neutrals in an annual raised-bed plasticulture system was viable, and planting plug plants of day-neutral cultivars in the fall, then harvesting in the spring, or planting dormant plants in the spring and harvesting through the fall was possible. However, it was unlikely that the increased yield alone would justify the cost of the tunnel. Growers have been quick to point out that the most important benefit of tunnel production has been the reliability of production, regardless of rain events during harvest, rather than increased yields. Harvesting in the spring, regardless of plant type, began 3 to 5 weeks earlier than typical for the same cultivars grown in the field, depending on the year.

Pests. A notable change from field production of small fruit crops was the change in the pest complex. The pest most consistently encountered on brambles and strawberry was the two-spotted spider mite, which was quite easily managed through the use of a mixture of predatory mites (Neoseiulus californicus and N. fallacis) as long as the predators were released when two-spotted mites were first observed. In 2006, sowbug and pillbug (Isopoda) and earwig (Dermaptera), which were thought to feed primarily on decomposing organic matter, were found to feed on ripe strawberry fruit, and were the leading cause of fruit loss. Losses in a tunnel of strawberry that was not part of the above studies approached $50 \%$. The tunnels at Rock Springs remain closed for the winter, primarily to help the structures better survive the nearly constant winds at this site. Because no more than the surface inch of soil ever froze during the course of the winter, it was likely that soil- and crown-dwelling insects were better able to survive winters, hence building to higher populations than were typical in field production.

Diseases were nearly nonexistent, presumably because the lack of moisture on the foliage minimized conditions needed for mycelial growth and sporulation. The most striking point is that it was quite easy to grow plants in a pesticide-free system. The one exception to this trend of reduced disease incidence was with powdery mildew on strawberry. Growers also have reported occasional outbreaks of powdery mildew, especially with the susceptible day-neutral strawberry 'Seascape'.

\section{Future research needs}

Many research projects result in more questions than answers, and our work with high tunnels was no exception. As covered in the discussion, many questions exist concerning explanations of why bramble crops performed as well as they did. In addition, different local growing conditions will result in different responses in tunnel production, and crops, cultivars, and growing systems that are best suited to local environments will vary and need to be explored. In addition, many questions exist concerning issues such as plant nutrition, amelioration of salinity, and pest management. One inherent problem with high tunnel research, and perhaps a reason that little work on high tunnels has been published in scientific literature, is that it is difficult to conduct replicated research that compares systems due to physical arrangements of facilities. Depending on the type of research intended, this should be considered early during the development of plans for high tunnel placement.

\section{Literature cited}

Couvillon, G.A. and A. Erez. 1985. Effect of level and duration of high temperatures on rest in the peach. J. Amer. Soc. Hort. Sci. 110:579-581.

Gaskell, M., D.J. Cantliffe, P.J. Stoffella, and N.L. Shaw. 2004. Field tunnels permit extended season harvest of small fruits in California. Acta Hort. 659:425430 .

Goulart, B.L. and K. Demchak. 1999. Performance of primocane fruiting red raspberries. Fruit Var. J. 53:32-40.

Hancock, J. and D. Simpson. 1995. Methods of extending the strawberry season in Europe. HortTechnology 5:286290.

Heidenreich, C., M. Pritts, M.J. Kelly, and K. Demchak. 2007. High tunnel raspberries and blackberries. Cornell University, Dept. Hort. Publ. No. 47.

Jett, L.W. 2007. Growing strawberries in high tunnels in Missouri. 17 July 2008. <http://www.hightunnels.org/PDF/ Growing_Strawberries_in_High_Tunnels. pdf $>$.

Kadir, S., E. Carey, and S. Ennahli. 2006. Influence of high tunnel and field conditions on strawberry growth and development. HortScience 41:329-335.

Lamont, W.J. 2005. Plastics: Modifying the microclimate for the production of vegetable crops. HortTechnology 15:477-481.

Lamont, W.J., M.D. Orzolek, E.J. Holcomb, K. Demchak, E. Burkhart, L. White, and B. Dye. 2003. Production system for horticultural crops grown in the Penn State high tunnel. HortTechnology 13:358-362.

Lamont, W.J., M.R. McGann, M.D. Orzolek, E.J. Holcomb, K. Demchak, L.D. White, B. Dye, T. Plummer, D. Reese, C. Thomas, P. Backman, C. Rasmussen, J. Harper, E. Sánchez, J. Garthe, R. Marini, D. Smith, and E. Burkhart. 2006. High tunnel production manual. 2nd edition. The Pennsylvania State Univ., College Agr. Sci. Ext. Publ. CP02-2.

Moore, M. 2000. These New Hampshire strawberries are no bleacher bums. 18 July 2008. <http://www.fruitgrowersnews. com / pages / $2000 /$ is sue $00 \_07 /$ issue00july_bleacher_berry.html>.

Privé, J.P. and N. Allain. 2000. Wind reduces growth and yield but not net leaf photosynthesis of primocane-fruiting 
red raspberries (Rubus idaeus L.) in the establishment years. Can. J. Plant Sci. 80:841-847.

U.S. Department of Agriculture. 2008. Noncitrus fruits and nut 2007 summary. 17 July 2008. <http://usda.mannlib.cor nell.edu/usda/current/NoncFruiNu/ NoncFruiNu-07-08-2008_revision.pdf $>$.
Vonweihe, M. and E. Hanson. 2008. Cold hardiness of red raspberry cultivars grown in high tunnels and the field. HortScience 43:1112. (Abstr.).

Wells, O.S. and J.B. Loy. 1993. Rowcovers and high tunnels enhance crop production in the northeastern United States. HortTechnology 3:92-94.
Wittwer, S.H. 1993. World-wide use of plastics in horticultural production. HortTechnology 3:6-19.

Wittwer, S.H. and N. Castilla. 1995. Protected cultivation of horticultural crops worldwide. HortTechnology 5:623. 